\title{
Reprogramming in vivo th17 into th17/th2 by Sirp- $\alpha$ dendritic cells in the lungs
}

\author{
Vu Quang Van*, Marianne Raymond, Keiko Wakahara, Manuel Rubio, Marika Sarfati \\ From Canadian Society of Allergy and Clinical Immunology Annual Scientific Meeting 2011 \\ Quebec, Canada. 20-23 October 2011
}

\section{Background}

Dendritic cells (DCs) play a crucial role in the development of the adaptive immune response. Unbalance DC response can cause Th1, Th17 or Th2-mediated diseases. By in vitro manipulation, Th2 and Th17 cell lines can be reprogrammed into Th1. This highlights the notion of the plasticity of different populations of CD4 $\mathrm{T}$ helper cells. So far, the conversion of Th17 memory cells into Th2 cells has not been demonstrated in the tissues.

\section{Methods}

Mice were immunized by repetitive administration of inflammatory DCs loaded with OVA protein antigen (OVA-DC), locally (intra-tracheal) or systematically (intravenous). Mice were sacrificed 24h after the last challenge and lymph nodes, serum, lungs and bronchoalveolar lavage were collected to evaluate the immune response.

\section{Results}

We showed here, that administration of OVA-DCs generated antigen-specific CD4 T cells that produced IL-17, IL-13 and IL-4 (Th17/Th2) and expressed GATA-3 in the lungs and the lymph nodes. The immunized mice developed an IgE-independent lung inflammation that displayed resistance to treatment with corticosteroids. This inflammation was characterized by a mixed infiltration of neutrophils and eosinophils in the bronchoalveolar lavage. We demonstrated that airway inflammatory SIRP-a DCs converted in vitro-generated Th17 but not Th2 cell lines into Th17/Th2. Finally, passive transfer of Th17/Th2 cells was sufficient to drive airway inflammation in naïve mice.

$\overline{\text { Immunoregulation Laboratory, Centre Hospitalier de I'Université de Montréal, }}$ Research Center CRCHUM, Notre-Dame Hospital, Montréal, Québec, H2L 4M1, Canada

\section{Conclusion}

We propose that immunization with inflammatory DCs, regardless of the route of immunization, induces chronic inflammation of the airways, which is associated with a Th2/Th17 response.

Published: 14 November 2011

doi:10.1186/1710-1492-7-S2-A27

Cite this article as: Quang Van et al:: Reprogramming in vivo th17 into th17/th2 by Sirp- $\alpha$ dendritic cells in the lungs. Allergy, Asthma \& Clinical Immunology 2011 7(Suppl 2):A27.
Submit your next manuscript to BioMed Central and take full advantage of:

- Convenient online submission

- Thorough peer review

- No space constraints or color figure charges

- Immediate publication on acceptance

- Inclusion in PubMed, CAS, Scopus and Google Scholar

- Research which is freely available for redistribution

Submit your manuscript at www.biomedcentral.com/submit
() Biomed Central

\section{Biomed Central}

